\title{
Understanding Management Roles and Organisational Behaviours in Planning and Scheduling Based on Construction Projects in Oman
}

\author{
*Hammad Al Nasseri and Radhlinah Aulin
}

Published online: 31 July 2016

To cite this article: Hammad Al Nasseri and Radhlinah Aulin. (2016). Understanding management roles and organisational behaviour in planning and scheduling based on construction projects in Oman. Journal of Construction in Developing Countries, 21 (1): 1-18. doi: 10.21315/jcdc2016.21.1.1

To link to this article: $h t t p: / / d x . d o i . o r g / 10.21315 / j c d c 2016.21 .1 .1$

Abstract: There are many challenges associated with the construction processes of planning and scheduling. These challenges are relevant to all project parties or stakeholders and therefore management roles or organisational behaviours of those parties have to be properly considered and assessed. With this in mind, this study is aimed at assessing practitioners' perspectives on the current significance and applicability of a set of criteria or factors concerned with management roles and organisational behaviours of the different parties based on construction projects in Oman. The study has adopted a quantitative approach in which a questionnaire-based survey was chosen and conducted to gather responses from construction projects in Oman. A total of 67 valid responses were analysed based on the rankings and means of the respondents' perspectives on the significance and applicability of the identified factors to current practice. The overall findings indicated that all investigated factors should be critically considered as equally important to the development process of planning and scheduling. Nevertheless, the findings implied that a management priority should be given to the most important factors significantly affecting project planning and scheduling. The study provides some useful recommendations on how to improve project management roles and organisational behaviours in planning and scheduling on the part of key project parties.

Keywords: Project control, Management roles, Organisational behaviour, Planning, Scheduling, Project parties, Oman

\section{INTRODUCTION}

The complexity of planning and scheduling tasks requires rigorous effort in terms of the effectiveness of the project team, especially with regard to the project management roles and organisational behaviours that are key factors for the success of project objectives (Mubarak, 2010; Ahuja and Thiruvengadam, 2004). This is because planning and scheduling should be managed and controlled in the most effective way by all team involved for a successful project performance (Kerzner, 2013). Therefore, the understanding of the impact of such roles and behaviours on work performance can provide tangible benefits to the success of the project (Yang, Huang and Wu, 2011). In this respect, a good alignment between the team's working behaviours (or human aspects) with the technical issues of a project will support the achievement of such benefits (Edum-Fotwe and McCaffer, 2000). According to Eriksson (2010), the effectiveness of any

Division of Construction Management, Lund University, SWEDEN

*Corresponding author: hammada@squ.edu.om

(C) Penerbit Universiti Sains Malaysia, 2016 
construction management process can be potentially improved by allowing for complete perceptions and interests from all construction stakeholders. For instance, Jaffar, Tharim and Shuib (2011) considered factors such as poor communication among the project team, lack of effective leadership and reluctance in controlling the project tasks execution and completeness as unintentional behaviours resulting in project disputes in terms of slow productivity and increased cost. A study by Cheung et al. (2003) implied that the consideration of behavioural aspects in the construction process still appears to be not sufficiently explored in current practices. More specifically, González et al. (2014) argued that there is a need to promote new management changes in project planning by clearly defining project management roles and their relevant impacts on the project performance. In addition, such management roles and behaviour, as well as other project technical issues should be effectively harmonised by all stakeholders involved in a project (Too and Weaver, 2014). In this regard, project stakeholders should be able to clearly identify and define all scheduling tasks, related resources and constraints for better project outcomes (Sears, Sears and Clough, 2010). According to Turner (1999), improving the performance of a project requires a competent management team that can monitor and control the project activities at both planning and operational levels of the project. Turner further argued that the competence of project management team in setting out a project plan, monitoring the work progress, estimating the schedule variance, as well as taking all necessary corrective actions are significant for the success of project planning (Turner, 1999).

This study was conducted based on the Oman construction projects. In this respect, the contribution of the construction industry to Oman's gross domestic product is forecasted at a growth rate ranging from $5 \%$ to $10 \%$ by 2020 , which represents a high proportion of the country's economy (Islam and Khadem, 2013; Oxford Business Group, 2014). According to the Oman regulation systems, large public projects of estimated cost above OMR 3 million (USD $1=$ OMR 0.385) are floated and awarded by the Oman tender board in a form of unit-cost or lumpsum contracts or other sorts of measurements (Oman Tender Board, 2014). There are, however, some exceptions for governmental authorities to manage certain types of projects internally through design-build contracts. All bidders participating in private and public projects, however, should follow the Oman Standards for Building and Civil Engineering Works as a regulated procedure. According to Oxford Business Group (2014), Oman, amongst many other developing countries, has also experienced some delays and improper cost control in a number of construction and infrastructure projects. Of course, all improper management issues causing these delays needed to be urgently addressed in a way that increased practitioners' awareness of what was lacking in their current practices. Despite this being the case, few academic studies conducted on the Omani construction industry revealed a common concern in the need for more evaluations of the current situational problems (or risk factors) pertaining to project disputes in terms of a lack of effective quality management, cost control systems and time performance measurements (Albalushi, Usman and Alnuaimi, 2013; Mohsin, 2011; Abu Hassan, Khalid and Onyeizu, 201 1; Alnuaimi et al., 2009; Bakar et al., 2012). But then, such performance measurements should also be focused on the other aspects concerned in the project management roles and organisational behaviours that might lead, if not properly understood and addressed, to 
ineffective planning and scheduling systems. To support this argument, it can be postulated that the effective consideration of such management roles and organisational behaviours in project planning and scheduling will help overcoming the occurrence of contractual disputes related to project planning during execution.

Summarising the above literature, there are far fewer examples to be considered when assessing the different project management roles and organisational behaviour attributed to key project stakeholders at particular stages such as planning and scheduling. These roles and behaviours should be considered and applied properly by all project stakeholders (or parties) involved in a project. Otherwise, insufficient considerations of such roles and behaviours will result in ineffective planning and scheduling, and thus low quality project execution. So, the originality of this study is based on its attempt to assess project management roles and organisational behaviour in construction planning and scheduling. This is important because giving a specific focus to the different roles and behaviours related to particular project tasks of planning and scheduling can be more worthwhile than looking at a project holistically. Consequently, this will improve the effectiveness of the implementation and control of these tasks; thus, enhancing their practical performance.

This study, therefore, aimed at addressing this lack of knowledge by identifying and assessing a set of factors concerned with management roles and organisational behaviour of the key project parties using the Oman construction projects. The primary goal was to answer the following research question: What are the management roles and organisational behaviours of project parties that should be critically considered for effective planning and scheduling?

In order to explore this research question, the following objectives were set:

1. To identify and examine project management roles and organisational behaviours of the key project parties involved in planning and scheduling

2. To provide new insights on how to improve the efficiency of such roles and behaviours in planning and scheduling.

The expected outcomes might provide useful insights for construction stakeholders and practitioners towards critically understanding and sufficiently addressing management roles and organisational behaviours for more effective planning and scheduling.

\section{LITERATURE REVIEW}

In addition to the above literature, there are a number of research studies studied and assessed various factors pertained to different project parties, which are considered as major reasons for poor project performance. However, some of these factors can be considered as team management roles and behaviours that should be independently investigated. In connection to this view, Nepal, Park and Son (2006) argued that project scheduling has a strong interaction with other metrics of a project and therefore is assumed to involve other management factors that to be critically considered. More specifically, Walker (2011) stated that organisational behaviour in the construction industry is still an issue that 
unquestionably needs more explicit exploration in practice. Latterly, this claim has been confirmed by Kreiner (2013) who argued that the effectiveness of the construction process can be best understood and improved by properly understanding the project management team and their organisational behaviour.

In summary, there seems to be a need for specific research studies on the understanding and assessment of project management roles and organisational behaviour in planning and scheduling in the context of construction projects. As noted earlier, much previous research, however, has paid more attention to the evaluation of the success and failure factors affecting project performance with regard to time and cost constraints (Assaf and Al-Hejji, 2006; Ahadzie, Proverbs and Olomolaiye, 2008; Ghosh and Jintanapakanont, 2004; Sun and Meng, 2009). Nevertheless, a number of these research studies have highlighted some initiatives regarding the assessment of potential effects of various factors, pertaining to the main participants (project managers, clients, contractors and consultants) in a project, on the success of project performance (Oyedele, 2013; Bari et al., 2012; Enshassi et al., 2007; Jaffar et al., 2011; Mbachu and Nkado, 2007; Doloi et al., 2012; Cooke-Davies, 2002; Sunindijo, Hadikusumo and Ogunlana, 2007; Hwang, Zhao and Goh, 2013). In a more recent study by Davis (2014), it is found, however, that there was no common agreement in perspectives among the different project stakeholders regarding the significance of these factors to their projects. This insignificant variation among stakeholders' view can be attributed to variability in project management roles and organisational behaviours currently adopted in project planning and scheduling. A summary of examples of investigated factors related to key project stakeholders or parties is presented in Table 1. As mentioned earlier, however, this study is trying to pay a more particular focus on the assessment of project management roles and organisational behaviours of the key project parties involved in the implementation and control of planning and scheduling.

Table 1. Summary of Findings of Some Relevant Research Studies

\begin{tabular}{|c|c|c|}
\hline & Examples of Investigated Factors & Selected Literatures \\
\hline 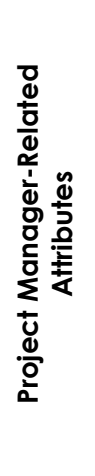 & $\begin{array}{l}\text { 1. Incomplete inputs of scope } \\
\text { 2. Aggressive designed schedules } \\
\text { 3. Incompetent planning } \\
\text { 4. Misunderstanding of the project } \\
\text { 5. Poecifications } \\
\text { 6. Ineffective communication } \\
\text { 7. Ineffective leadership } \\
\text { 8. Insufficient identification of } \\
\text { 9. } \text { Reundary conditions } \\
\text { 10. Shortage of resources }\end{array}$ & $\begin{array}{l}\text { Ahadzie, Proverbs and Olomolaiye } \\
\text { (2008); Assaf and Al-Hejji (2006); } \\
\text { Belassi and Tukel (1996); Enshassi et } \\
\text { al. (2007); Mbachu and Nkado } \\
\text { (2007); Cooke-Davies (2002) }\end{array}$ \\
\hline
\end{tabular}

(continued on next page) 
Table 1. (continued)

\begin{tabular}{|c|c|c|}
\hline & Examples of Investigated Factors & Selected Literatures \\
\hline 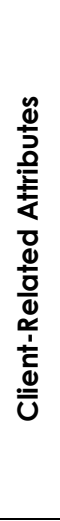 & $\begin{array}{l}\text { 1. Poor organisation structure } \\
\text { 2. Inaccurate regulations by client's } \\
\text { representatives } \\
\text { 3. Centralised management } \\
\text { 4. Project financing and interim } \\
\text { payments } \\
\text { 5. Uncontrolled variation orders } \\
\text { 6. Less involvement in planning } \\
\text { 7. Lack of team training } \\
\text { 8. Ambiguity of requirements } \\
\text { 9. Access restriction to site information } \\
\text { 10. Lack of conflict management plan }\end{array}$ & $\begin{array}{l}\text { Ahadzie, Proverbs and Olomolaiye } \\
\text { (2008); Assaf and Al-Hejji (2006); } \\
\text { Enshassi et al. (2007); Hwang, Zhao } \\
\text { and Goh (2013); Doloi et al. (2012) }\end{array}$ \\
\hline 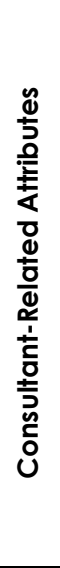 & $\begin{array}{l}\text { 1. Complexity of design } \\
\text { 2. Inaccurate cost estimate } \\
\text { 3. Planning errors } \\
\text { 4. Insufficient consideration of } \\
\text { 5. Incompetent technical team } \\
\text { 6. Improper inspections } \\
\text { 7. Use of obsolete design criteria } \\
\text { 8. Unreliability of schedules } \\
\text { 9. Lack of control methods } \\
\text { 10. Insufficient coordination } \\
\text { 11. Unrealistic resource forecast } \\
\text { 12. Ignorance of non-technical aspects } \\
\text { in design }\end{array}$ & $\begin{array}{l}\text { Faridi and El-Sayegh (2006); Assaf } \\
\text { and Al-Hejji (2006); Enshassi et al. } \\
\text { (2007); Ibironke et al. (2013) }\end{array}$ \\
\hline 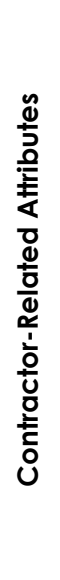 & $\begin{array}{l}\text { 1. Faulty implementation of plans } \\
\text { 2. Lack of control over sub-contractors } \\
\text { 3. Delays in procurement and delivery } \\
\text { schedules } \\
\text { 4. Improper use of equipment and } \\
\text { construction testing } \\
\text { 5. Unreliable progress reports } \\
\text { 6. Lack of partnering and } \\
\text { interdisciplinary } \\
\text { 7. Financial constraints } \\
\text { 8. Weak motivated and low- } \\
\text { 9. Improper rescheduling of actual } \\
\text { 10. Lack of new technology }\end{array}$ & $\begin{array}{l}\text { Faridi and El-Sayegh (2006); Ghosh } \\
\text { and Jintanapakanont (2004); Assaf } \\
\text { and Al-Hejji (2006); Ibironke et al. } \\
\text { (2013); Mbachu and Nkado (2007); } \\
\text { Enshassi et al. (2007) }\end{array}$ \\
\hline
\end{tabular}




\section{METHODOLOGY}

\section{Identification of the Study Variables}

In view of the literature review and the subsequent discussions, the current practices in project planning and scheduling, not least in Oman, take very little account of stakeholders or practitioners' perspectives regarding the understanding of project management roles and organisational behaviours currently embraced in the development, implementation and control of project planning and scheduling. Considering this lack of knowledge indicated in the literature and by using experiences of the researcher in the construction industry and subsequently utilising brainstorming, a screened list of 44 factors was identified and designed. The identified factors were presumed to contribute to the project management roles and organisational behaviours of the four main parties, usually involved at a certain level of participation in project management tasks of planning and scheduling. Out of a total of 44 defined factors, 14 criteria related to project managers' roles and behaviour in planning and scheduling, 10 to clients' roles and behaviours, 10 to contractors' roles and behaviours and 10 to consultants' roles and behaviours.

\section{Data Collection Methods}

The study has adopted a questionnaire-based survey, which is considered a positivist tool for gathering data about research problems where their relevant theory seems to be inadequately investigated in practice (Neuman, 2005). In this study, the questionnaire was distributed manually (hand-delivered copies) and electronically (mail-delivered copies) to groups of people engaged in a number of public and private construction organisations in Oman. The questionnaire tested the strength of the participant perspectives on the significance of the adopted factors based on a Likert-type point scale of 1 to 7 , where 1 represents the lowest level of disagreement (strongly disagree) and 7 represents the highest level of agreement (strongly agree). The questionnaire was responded by 67 participants out of about 120 distributed copies; which is $55.8 \%$ response rate which can be considered as a reasonable response rate. Table 2 presents the analysis of the respondents' profiles.

Table 2. Background Profiles of Respondents

\begin{tabular}{llcc}
\hline Characteristics & Responses & $\begin{array}{c}\text { Percentage } \\
\text { Frequency } \\
\text { (Count) }\end{array}$ & $\begin{array}{c}\text { (\%) } \\
\text { Work position }\end{array}$ \\
& Senior engineers & 26 & 38.8 \\
& Project managers & 22 & 32.8 \\
& Junior engineers & 17 & 25.4 \\
& Quantity surveyors & 2 & 3.0 \\
\hline
\end{tabular}

(continued on next page) 
Table 2. (continued)

\begin{tabular}{|c|c|c|c|}
\hline Characteristics & & $\begin{array}{c}\text { Responses } \\
\text { Frequency } \\
\text { (Count) }\end{array}$ & $\begin{array}{l}\text { Percentage } \\
(\%)\end{array}$ \\
\hline \multirow[t]{3}{*}{ Qualifications } & Degree & 45 & 67.2 \\
\hline & Master & 12 & 17.9 \\
\hline & Diploma & 10 & 14.9 \\
\hline \multirow[t]{5}{*}{ Years of experience } & $5-10$ & 18 & 27.0 \\
\hline & $11-16$ & 14 & 19.5 \\
\hline & $17-22$ & 19 & 28.4 \\
\hline & $>22$ & 14 & 19.5 \\
\hline & Not defined & 2 & 3.0 \\
\hline \multirow[t]{4}{*}{ Type of firm/organisation } & Clients & 28 & 41.8 \\
\hline & Contractors & 22 & 32.8 \\
\hline & Project management & 13 & 19.4 \\
\hline & Consultants & 4 & 6.0 \\
\hline \multirow{9}{*}{$\begin{array}{l}\text { Phases of project } \\
\text { respondents are currently } \\
\text { involved in }\end{array}$} & All & 19 & 30.6 \\
\hline & Execution & 13 & 20.9 \\
\hline & Planning and controlling & 9 & 14.5 \\
\hline & Execution and controlling & 6 & 9.7 \\
\hline & $\begin{array}{l}\text { Initiating, planning and } \\
\text { execution }\end{array}$ & 5 & 8.0 \\
\hline & Controlling & 5 & 8.0 \\
\hline & Planning and execution & 4 & 6.5 \\
\hline & Initiating & 1 & 1.6 \\
\hline & Not defined & 5 & 7.5 \\
\hline \multicolumn{2}{|l|}{ Total } & 67.0 & - \\
\hline
\end{tabular}

\section{Data Analysis Methods}

The study has considered the relative importance index (RII) for testing the collected data. Holt (2014) considered the Rll as a suitable tool to provide more accurate rankings of responses collected through a study-based Likert-scale questionnaires than descriptive statistics. In this regard, Holt revised and modified the RIl models for the aim of providing more precise estimations of the intervals of the rankings among the tested variables. Thus, the Rll rankings and means of the study variables were computed based on the following equations recently developed by Holt (2014):

$\mathrm{Rll}_{(7-\text { point, adjusted model })}=\left(\left[116.68\left(\sum \mathrm{W} \div 7 \mathrm{~N}\right)\right]-16.68\right) \%$

Eq. 1

Based on Holt (2014), where $\sum w$ (for a seven-point Likert-scale) $=\left(7^{*} n_{7}+6^{*} n_{6}+5^{*} n_{5}\right.$ $\left.+4^{*} n_{4}+3^{*} n_{3}+2^{*} n_{2}+n_{1}\right)$

$\mathrm{R} \|_{\text {(max range })}=1-\left(1 \div A_{\text {max }}\right)=0.86$

RIImean $=$ SQRT. $(R I I)$

Eq. 2 
Where $\mathrm{R} I \mathrm{l}=$ relative importance index, $\mathrm{w}=$ individual weight given to each statement based on a seven-point scale (stems), $A_{\max }=$ the highest ranking point used ( 7 in this study) and $N=$ the total number of respondents used in the analysis. It should be noted that the respondents were asked to rank the identified factors in the study based on the relevance or applicability of these different factors to the current practice of their construction projects. For the purpose of management priorities and practical considerations of the most significant factors (roles and behaviours), the data interpretation is based on the Rll analysis of the top five factors as discussed next.

\section{DATA ANALYSIS AND DISCUSSIONS}

\section{Management Roles and Organisational Behaviours Related to Project Managers}

The results in Table 3 indicated that respondents assigned close RIl rankings to the significance of project manager roles and behaviours to planning and scheduling. Project manager roles and behaviours concerned with the practical use of project scheduling as tool-based managerial skills rather than tool-based computer skills $(F 1$; Mean $=0.424$; Rlladjusted $=0.848)$ and motivational incentives for successful planning and scheduling teams (F8; Mean $=0.423$; R $\|_{\text {adjusted }}=0.846$ ) were ranked as the most important factors to the current practice. In view of these findings, a study by González et al. (2014) revealed that a proper understanding of project schedules by project managers is crucial to the effective control of schedule deviations during project execution. This would imply that managerial motivations assigned for the successful planning team can improve the project team productivity in managing a more realistic and controllable scheduling.

Other roles and behaviours concerning project manager competence in understanding the complete transfer of planning outputs into scheduling plans (F6; Mean $=0.418$; Rlladjusted $=0.836$ ) and the best use of lessons learned when developing new project plans and schedules (F10; Mean $=0.418$; Rlladjusted $=0.836$ ) were received the same RIl ranks as equally important factors to the current practice of planning and scheduling. This has become evident in view of the literature which implied that insufficient considerations of all inputs and deliverables in project planning will result in impractical scheduling of the project (Nepal, Park and Son, 2006; Ahsan and Gunawan, 2010). This results can imply that project managers should not proceed with project scheduling unless project planning is measured against the completeness of scope definition, especially time and resources estimates. 
Table 3. RIl Rankings of Project Managers' Roles and Organisational Behaviour

\begin{tabular}{|c|c|c|c|c|}
\hline \multirow{2}{*}{\multicolumn{2}{|c|}{$\begin{array}{l}\text { Organisational Roles and Behaviours of Project Managers in } \\
\text { Descending Order }\end{array}$}} & \multicolumn{3}{|c|}{ RIl adjusted } \\
\hline & & \multirow{2}{*}{$\frac{\text { Mean }}{0.424}$} & \multirow{2}{*}{$\begin{array}{l}\text { Value } \\
0.848\end{array}$} & \multirow{2}{*}{$\frac{\text { Rank }}{1}$} \\
\hline $\mathrm{Fl}$ & $\begin{array}{l}\text { Practicing the schedule as management based-skills rather } \\
\text { than computer based-skills }\end{array}$ & & & \\
\hline F8 & $\begin{array}{l}\text { Motivating and rewarding the successful planning and } \\
\text { scheduling team }\end{array}$ & 0.423 & 0.846 & 2 \\
\hline F6 & $\begin{array}{l}\text { Ensuring accuracy and completeness of all outputs from } \\
\text { planning to scheduling }\end{array}$ & & 0.836 & 3 \\
\hline F10 & $\begin{array}{l}\text { Applying past lessons gained for developing the new plans } \\
\text { and schedules }\end{array}$ & & 0.836 & 3 \\
\hline F3 & $\begin{array}{l}\text { Cooperating with cross-functional team in all stages of } \\
\text { planning and scheduling }\end{array}$ & & 0.823 & 4 \\
\hline F2 & $\begin{array}{l}\text { Using the schedule as an effective communicating tool for } \\
\text { information sharing and learning }\end{array}$ & 0.411 & 0.821 & 5 \\
\hline F9 & $\begin{array}{l}\text { Monitoring and guiding site managers on the actual } \\
\text { scheduling }\end{array}$ & 0.406 & 0.813 & 6 \\
\hline F7 & $\begin{array}{l}\text { Setting-out the efficient methodologies for controlling the } \\
\text { implementation of plans and schedules }\end{array}$ & 0.399 & 0.798 & 7 \\
\hline F5 & $\begin{array}{l}\text { Understanding the key characteristics of the adopted } \\
\text { planning methods }\end{array}$ & 0.338 & 0.776 & 8 \\
\hline $\mathrm{F} 11$ & $\begin{array}{l}\text { Fostering innovative systems in planning to overcome } \\
\text { shortcomings with traditional systems }\end{array}$ & 0.383 & 0.766 & 9 \\
\hline F13 & $\begin{array}{l}\text { Adopting flexible procedures to allow for dynamic planning } \\
\text { and scheduling }\end{array}$ & 0.379 & 0.758 & 10 \\
\hline F4 & $\begin{array}{l}\text { Allowing all needs and inputs from project stakeholders in } \\
\text { planning }\end{array}$ & 0.378 & 0.756 & 11 \\
\hline $\mathrm{F} 12$ & $\begin{array}{l}\text { Delegating authority to site managers for taking necessary } \\
\text { actions on the schedule deviations }\end{array}$ & 0.376 & 0.751 & 12 \\
\hline $\mathrm{F} 14$ & $\begin{array}{l}\text { Understanding the team cultural differences in planning and } \\
\text { scheduling }\end{array}$ & 0.360 & 0.719 & 13 \\
\hline
\end{tabular}

\section{Management Roles and Organisational Behaviours Related to Clients}

The Rll results revealed a small variation in the overall rankings of the studied roles and behaviours of clients as indicated in Table 4. Nevertheless, there is still a room for prioritising some significant factors than others while developing project plans and schedules. In this regard, the clients' roles and behaviours concerned with sufficient awareness about the impact of unplanned changes on the original schedule (F22; Mean $=0.387$; Rlladjusted $=0.774$ ) and the participation in coordinating and setting out the measurement performance tools for planning and scheduling (F18; Mean $=0.385$; Rlladjusted $=0.771$ ), as well as clients' flexibility in facilitating the flow of the project boundary information in planning and scheduling (F17; Mean = 0.383; Rlladjusted $=0.766$ ), were ranked as the top three factors that might be given more attention. The findings can imply that clients should play a strong role in setting out the performance control tools, as well as 
they should use their own competencies when addressing and evaluating their needs and relevant impacts on planning. Additionally, clients should be authentic regarding desired information needed about project boundary conditions for a more reliable project planning. Other management roles concerned with the completeness and accuracy of needs and inputs in planning on the part of clients was considered as the fourth significant factor (F16; Mean $=0.381$; Rll adjusted $=$ 0.762). This factor was followed by project clients' roles or behaviours concerning the ability to establish trustworthy and interactive environments in planning and scheduling (F15; Mean $=0.378$; Rlladjusted $=0.756$ ) ranked as the fifth significant factor. A combination of these findings aligned with the same concern indicated in the relevant literature stating that the client ability to allocate contingency resources (buffers) and ability to actively participate in project planning, as well as the ability to efficiently overcome any schedule deviations during the implementation stage are significant issues to the success of project time performance (Ahadzie, Proverbs and Olomolaiye, 2008; Hwang, Zhao and Goh, 2013; Mbachu and Nkado, 2007).

Table 4. Rll Rankings of Clients' Roles and Organisational Behaviours

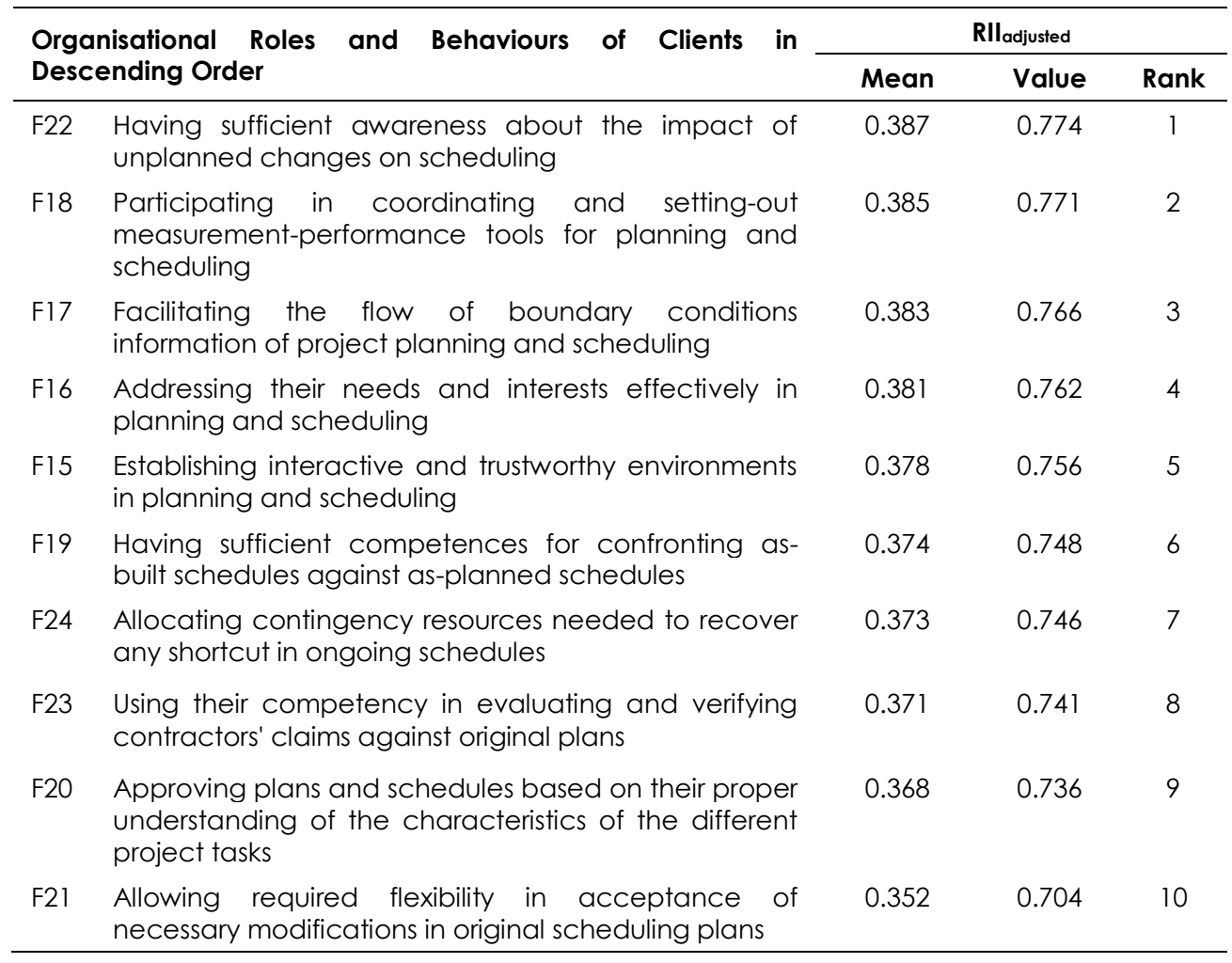

10/PENERBIT UNIVERSITI SAINS MALAYSIA 


\section{Management Roles and Organisational Behaviours Related to Consultants}

Table 5 presents the overall rankings and means of the factors used to judge roles and behaviours of project consultants in planning and scheduling. The results revealed that the factors identified as effective coordination with all project stakeholders in the implementation and control of planning and scheduling (F28; Mean $=0.389$; Rlladjusted $=0.778$ ) was rated with the highest Rll value as the most important role to be considered. A more recent study by Oyedele (2013) revealed that the effectiveness of consultants' co-ordination with other project stakeholders is a key issue for the effectiveness of project planning, especially in mega projects where many stakeholders are involved at different design stages. Subsequently, the findings from the study indicated that management roles and organisational behaviours of consultants concerned with the efficiency in transferring all information, needs and other inputs of stakeholders in planning (F27; Mean = 0.377; Rlladjusted $=0.754)$, the effectiveness in analysing the scheduling outcomes in conformance quality and risk aspects of project (F29; Mean $=0.377$; Rll adjusted $=$ 0.754 ) and the tendency to be proactive regarding uncertainties or risk factors causing hindrance to the schedule performance (F31; Mean $=0.376$; Rll adjusted $=$ 0.751 ) were considered as equally important factors to the implementation and control of project planning and scheduling. In connection to this, it was argued that delegating a more proactive team is crucial for identifying all potential risks and for allocating contingency plans; thus, mitigating uncertainty in scheduling by effectively managing risks (Schatteman et al., 2008).

Moreover, the results showed that the factor concerned with the consultant capability to adopt a variety of control methods and tools in project planning and scheduling was received the fourth RII score (F25; Mean $=0.374 ;$ Rll $_{\text {adjusted }}=0.749$ ). This would imply that project consultants should understand, choose and adopt the most suitable tools and methods that fit with the project nature (size and complexity) for managing a more realistic scheduling that meets the common understanding of other project parties.

Table 5. RIl Rankings and Means of Consultants' Roles and Organisational Behaviours

\begin{tabular}{llccc}
\hline \multirow{2}{*}{$\begin{array}{l}\text { Organisational Roles and Behaviours of Consultants in Descending } \\
\text { Order }\end{array}$} & \multicolumn{3}{c}{ RIladjusted } \\
\cline { 2 - 4 } & Mean & Value & Rank \\
\hline F28 & $\begin{array}{l}\text { Coordinating effectually with other project parties for the } \\
\text { improper implementation and control in planning and } \\
\text { scheduling }\end{array}$ & 0.389 & 0.778 & 1 \\
F27 & $\begin{array}{l}\text { Liaising with all project stakeholders to efficiently transfer their } \\
\text { inputs and needs in planning }\end{array}$ & 0.377 & 0.754 & 2 \\
F29 $\quad \begin{array}{l}\text { Evaluating and analysing planning and scheduling outcomes } \\
\text { in relation to the project quality and risk aspects }\end{array}$ & 0.377 & 0.754 & 2 \\
F31 $\begin{array}{l}\text { Working as proactive team regarding all uncertainties or risks } \\
\text { anticipated in scheduling }\end{array}$ & 0.376 & 0.751 & 3 \\
\hline
\end{tabular}


Table 5. (continued)

\begin{tabular}{|c|c|c|c|c|}
\hline \multirow{2}{*}{\multicolumn{2}{|c|}{$\begin{array}{l}\text { Organisational Roles and Behaviours of Consultants in Descending } \\
\text { Order }\end{array}$}} & \multicolumn{3}{|c|}{ RIl adjusted } \\
\hline & & \multirow{2}{*}{$\begin{array}{c}\text { Mean } \\
0.374\end{array}$} & \multirow{2}{*}{$\begin{array}{l}\text { Value } \\
0.749\end{array}$} & \multirow{2}{*}{$\begin{array}{c}\text { Rank } \\
4\end{array}$} \\
\hline F25 & $\begin{array}{l}\text { Experiencing their proficiency in adopting alternate planning } \\
\text { and scheduling methods }\end{array}$ & & & \\
\hline F33 & $\begin{array}{l}\text { Adopting change in management for assessing all required } \\
\text { changes and subsequent effects on planning }\end{array}$ & 0.370 & 0.739 & 5 \\
\hline F32 & $\begin{array}{l}\text { Utilising the efficient control systems for collecting feedbacks } \\
\text { on actual performance of scheduling }\end{array}$ & 0.368 & 0.736 & 6 \\
\hline F26 & $\begin{array}{l}\text { Recognising and admitting their responsibility towards } \\
\text { technical inputs faults in planning and scheduling }\end{array}$ & 0.362 & 0.724 & 7 \\
\hline F34 & $\begin{array}{l}\text { Adequately considering all new claims or concerns from } \\
\text { project stakeholders in the implementation of planning and } \\
\text { scheduling }\end{array}$ & 0.361 & 0.721 & 8 \\
\hline F30 & $\begin{array}{l}\text { Identifying all constraints in planning to avoid any deviation } \\
\text { from original plans in scheduling }\end{array}$ & 0.346 & 0.692 & 9 \\
\hline
\end{tabular}

\section{Management Roles and Organisational Behaviours Related to Contractors}

Table 6 presents the Rll rankings of the factors used to examine the contractor roles and behaviours in planning and scheduling. It is also very important to understand the contractor roles in the development and control of project planning and scheduling. More recently, Alzahrani and Emsley (2013) have stated that proper understanding of performance aspects and management roles of project contractors is crucial for the best likelihoods of having more achievable outcomes from the execution of construction projects. The results in Table 6 indicated that the factors concerned with the contractor effectiveness in following up and controlling in-site teams and in resolving their related conflicts affecting the schedule performance (F37; Mean $=0.417$; Rlladjusted $=0.833$ ), as well as the contractor competence in adequately incorporating and managing work schedules of sub-contractors and suppliers in the main project scheduling (F38; Mean $=0.414$; Rlladjusted $=0.828$ ), received the highest Rll ranks as significant roles or organisational behaviours to the implementation and control of planning and scheduling. This was followed by the factor concerning the contractor role and behaviours towards admitting the accountability for the most efficient technical implementation of project plans and schedules (F35; Mean $=0.412$; Rlladjusted $=$ 0.823). In addition, the contractor should also be able to manage all interferences between procurement schedules and the project schedule (F36; Mean = 0.408; Rlladjusted $=0.816$ ), as well as the ability to update project schedules resourcefully based on feedbacks from other project stakeholders (F40; Mean = 0.398; Rlladjusted $=0.796)$. In this regard, scheduling quality control can be enhanced by adequate identifying of the interference impacts in the material delivery schedule on the detailed scheduling of a project (Oberlender, 1993; Belout and Gauvreau, 2004). These roles and behaviours of contractors should be critically considered for high quality performance of scheduling. Other relevant studies by Iyer and Jha (2006), Jha and lyer (2007) and lbironke et al. (2013) also indicated the imperative of 
considering such factors, amongst other important factors (Table 1), while managing construction scheduling.

Table 6. RIl Rankings of Contractors' Roles and Organisational Behaviours

\begin{tabular}{|c|c|c|c|c|}
\hline \multirow{2}{*}{\multicolumn{2}{|c|}{$\begin{array}{l}\text { Organisational Roles and Behaviours of Contractors in } \\
\text { Descending Order }\end{array}$}} & \multicolumn{3}{|c|}{ RII ${ }_{\text {adjusted }}$} \\
\hline & & \multirow{2}{*}{$\frac{\text { Mean }}{0.417}$} & \multirow{2}{*}{$\begin{array}{l}\text { Value } \\
0.833\end{array}$} & \multirow{2}{*}{$\frac{\text { Rank }}{1}$} \\
\hline F37 & $\begin{array}{l}\text { Following-up and supervising the site labour for the } \\
\text { effective implementation of schedules }\end{array}$ & & & \\
\hline F38 & $\begin{array}{l}\text { Incorporating all sub-contractors and suppliers work } \\
\text { schedules in the master scheduling effectively }\end{array}$ & 0.414 & 0.828 & 2 \\
\hline F35 & $\begin{array}{l}\text { Admitting the accountability for the efficient } \\
\text { implementation of plans and schedules }\end{array}$ & 0.412 & 0.823 & 3 \\
\hline F36 & $\begin{array}{l}\text { Managing interferences properly among the delivery } \\
\text { scheduling and the project master scheduling }\end{array}$ & 0.408 & 0.816 & 4 \\
\hline F40 & $\begin{array}{l}\text { Updating scheduling resourcefully based on all } \\
\text { criticisms or feedbacks from the other project parties }\end{array}$ & 0.398 & 0.796 & 5 \\
\hline F39 & $\begin{array}{l}\text { Embracing the schedule contingency properly in } \\
\text { overcoming unexpected events or variances }\end{array}$ & 0.393 & 0.786 & 6 \\
\hline F41 & $\begin{array}{l}\text { Suggesting and elevating alternate scenarios for } \\
\text { addressing the schedule constraints }\end{array}$ & 0.390 & 0.779 & 7 \\
\hline F43 & $\begin{array}{l}\text { Supporting the implementation of planning and } \\
\text { scheduling by adopting the most appropriate } \\
\text { monitoring techniques }\end{array}$ & 0.380 & 0.759 & 8 \\
\hline F44 & $\begin{array}{l}\text { Engaging specialised team in analysing the scheduling } \\
\text { severities or disputes }\end{array}$ & 0.366 & 0.731 & 9 \\
\hline F42 & $\begin{array}{l}\text { Documenting all concerns and claims effectually from } \\
\text { other project parties }\end{array}$ & 0.353 & 0.706 & 10 \\
\hline
\end{tabular}

\section{PRACTICAL IMPLICATIONS FOR MANAGERIAL CONSIDERATIONS}

Based on the findings and subsequent discussions, the significant factors concerned with roles and organisational behaviours should be integrated into the current philosophies of project planning adopted in the construction industry. As a result, construction practitioners and key stakeholders should be able to properly identify and adjust the existing management roles and organisational behaviours for the purpose of managing more dynamic and effective planning and scheduling systems. The project parties should be able to address, amongst other management roles and behaviours, the following issues, which can be used as guidelines in making the most effective decision in project planning and scheduling:

1. Project managers should effectively recognise that their accountability is not limited to planning, but should also be extended and communicated to the implementation and control of project plans and schedules. Project managers should give specific focus to the improvement of their team skills in managing effective project scheduling. It can be achieved through specific training on planning and scheduling theory, the use of control tools and other computerised techniques. In addition, project managers should 
be competent in setting out the most efficient control and communication plans with other parties in the project in order to allow more realistic information sharing and feedback.

2. Clients should be competent in and increase their awareness of the consequences of any uncontrolled or poorly planned changes on the effectiveness of planning and scheduling systems. Therefore, they should actively participate in coordinating and establishing the most efficient measurement tools or methodologies for planning and scheduling. Moreover, clients should be very flexible and realistic when providing and addressing all required information to other stakeholders about project boundary conditions in planning. They should be competent in addressing their needs and interests on the basis of real needs behind the project idea.

3. Consultants should be effectively coordinating all inputs and deliverables from other parties in planning and scheduling which means that consultants should be able to transfer such needs into well-defined, measurable units in planning. The consultants should be able to foster any required change in the management plan, for example, by applying new tools and techniques for controlling and analysing all uncertainties in the schedule against other measures of quality, risk and cost control.

4. Contractors should be competent in applying planned and scheduled tasks into physical actions, as well as effectively communicate with their in-site team in order to be able to follow-up the implementation of such tasks on site according to the original plan. Moreover, they should be able to adequately manage interferences among materials' delivery schedules and master the work schedule to prohibit any detraction from the original plans. In this regard, they should utilise monitoring and optimisation tools to precisely identify any deviations in scheduling and rapidly address them to other stakeholders for necessary corrective action with no cost implications.

\section{CONCLUSIONS}

The study has identified and examined a set of factors identified as project management roles and organisational behaviours of the main project parties in project planning and scheduling. The literature review implied that there is a lack of knowledge on the part of construction practitioners towards the proper understanding of such roles and behaviours in the current practice. The research findings revealed that there is a strong level of agreement among the respondents on the rankings of significance of the investigated factors to planning and scheduling. Nevertheless, the study implied that there is a need to prioritise certain significant roles and behaviours than others while developing project plans and schedules. In addition, construction policy-makers should take into account that any mismatch in project management roles and organisational behaviours of the main project parties involved can result in ineffective planning and scheduling.

Despite the study being limited to locally perspectives based on the Oman construction projects, it has provided some useful insights to construction practitioners and stakeholders in general. First, it highlights a new management area concerned with organisational behaviours in project planning which appears to be a relatively new concept that needs further investigations. Second, it has 
provided useful knowledge regarding the rankings of the different roles and organisational behaviours to current practice; thus, construction practitioners are expected to obtain new information on how to prioritise certain management roles by adjusting their current planning strategies for the best development and control in planning and scheduling. The study results might be externally validated by adopting a more rigorous approach to develop a deeper insight about the research phenomena highlighted in this study.

\section{REFERENCES}

Abu Hassan, A.B., Khalid, A. and Onyeizu, E. (2011). Total quality management practices in large construction companies: A case of Oman. World Applied Sciences Journal, 15(2): 285-296.

Abu Hassan, A.B., Khalid, A., Onyeizu, E.N. and Mohamad Nizam, Y. (2012). Evaluating risk management practices in construction industry: Evidence from Oman. International Journal of Academic Research, 4(2): 32-36.

Ahadzie, D.K., Proverbs, D.G. and Olomolaiye, P.O. (2008). Critical success criteria for mass house building projects in developing countries. International Journal of Project Management, 26(6): 675-687. doi: 10.1016/j. ijproman.2007.09.006.

Ahsan, K. and Gunawan, I. (2010). Analysis of cost and schedule performance of international development projects. International Journal of Project Management, 28(1): 68-78. doi: 10.1016/j.jproman.2009.03.005.

Ahuja, V. and Thiruvengadam, V. (2004). Project scheduling and monitoring: Current research status. Construction Innovation, 4(1): 19-31. doi: $10.1108 / 14714170410814980$.

Albalushi, I.A., Usman, F. and Alnuaimi, A.S. (2013). Appraisal of value engineering in construction industry in Oman. 13 Value Practices Completion Certificate: A Proposal to Confirm the Successful Completion of Value Practices Studies, 36(2): 37.

Alnuaimi, A.S., Taha, R.A., Al Mohsin, M. and Al-Harthi, A.S. (2009). Causes, effects, benefits and remedies of change orders on public construction projects in Oman. Journal of Construction Engineering and Management, 136(5): 615-622. doi: 10.1061/(ASCE)CO.1943-7862.0000154.

Alzahrani, J.I. and Emsley, M.W. (2013). The impact of contractors' attributes on construction project success: A post construction evaluation. International Journal of Project Management, 31(2): 313-322. doi: 10.1016/ j.ijproman.2012.06.006.

Assaf, S.A. and Al-Hejji, S. (2006). Causes of delay in large construction projects. International Journal of Project Management, 24(4): 349-357. doi: 10.1016/j.jproman.2005.11.010.

Bari, N.A.A., Yusuff, R., Ismail, N., Jaapar, A. and Ahmad, R. (2012). Factors influencing the construction cost of industrialised building system (IBS) projects. Procedia-Social and Behavioral Sciences, 35: 689-696. doi: 10.1016/j.sbspro.2012.02.138.

Belassi, W. and Tukel, O.I. (1996). A new framework for determining critical success/failure factors in projects. International Journal of Project Management, 14(3): 141-151. doi: 10.1016/0263-7863(95)00064-X. 
Belout, A. and Gauvreau, C. (2004). Factors influencing project success: The impact of human resource management. International Journal of Project Management, 22(1): 1-11. doi: 10.1016/\$0263-7863(03)00003-6.

Cheung, S.O., Ng, T.S.T., Wong, S.-P. and Suen, H.C.H. (2003). Behavioral aspects in construction partnering. International Journal of Project Management, 21 (5): 333-343. doi: 10.1016/\$0263-7863(02)00052-2.

Cooke-Davies, T. (2002). The "real" success factors on projects. International Journal of Project Management, 20(3): 185-190. doi: 10.1016/50263-7863(01)00067-9.

Davis, K. (2014). Different stakeholder groups and their perceptions of project success. International Journal of Project Management, 32(2): 189-201. doi: 10.1016/j.jproman.2013.02.006.

Doloi, H., Sawhney, A., Iyer, K.C. and Rentala, S. (2012). Analysing factors affecting delays in Indian construction projects. International Journal of Project Management, 30(4): 479-489. doi: 10.1016/j.jproman.2011.10.004.

Edum-Fotwe, F. and McCaffer, R. (2000). Developing project management competency: Perspectives from the construction industry. International Journal of Project Management, 18(2): 111-124. doi: 10.1016/S02637863(98)90075-8.

Enshassi, A., Mohamed, S., Mustafa, Z.A. and Mayer, P. (2007). Factors affecting labour productivity in building projects in the Gaza strip. Journal of Civil Engineering and Management, 13(4): 245-254.

Eriksson, P.E. (2010). Understanding the construction client. Construction Management and Economics, 28(11): 1197-1198. doi: 10.1080/ 01446191003702450.

Faridi, A.S. and El-Sayegh, S.M. (2006). Significant factors causing delay in the UAE construction industry. Construction Management and Economics, 24(11): 1167-1176. doi: 10.1080/01446190600827033.

Ghosh, S. and Jintanapakanont, J. (2004). Identifying and assessing the critical risk factors in an underground rail project in Thailand: $A$ factor analysis approach. International Journal of Project Management, 22(8): 633-643. doi: 10.1016/j.jproman.2004.05.004.

González, P., González, V., Molenaar, K. and Orozco, F. (2014). Analysis of causes of delay and time performance in construction projects. Journal of Construction Engineering and Management, 140(1): 04013027. doi: 10.1061/(ASCE)CO.1943-7862.0000721.

Holt, G.D. (2014). Asking questions, analysing answers: Relative importance revisited. Construction Innovation, 14(1): 2-16. doi: 10.1108/CI-06-20120035.

Hwang, B.G., Zhao, X. and Goh, K.J. (2013). Investigating the client-related rework in building projects: The case of Singapore. International Journal of Project Management. Forthcoming.

Ibironke, O.T., Oladinrin, T.O., Adeniyi, O. and Eboreime, I.V. (2013). Analysis of nonexcusable delay factors influencing contractors' performance in Lagos State, Nigeria. Journal of Construction in Developing Countries, 18(1): 5372.

Islam, M.A. and Khadem, M.M.R.K. (2013). Productivity determinants in Oman construction industry. International Journal of Productivity and Quality Management, 12(4): 426-448. doi: 10.1504/IJPQM.2013.056736. 
Iyer, K. and Jha, K. (2006). Critical factors affecting schedule performance: Evidence from Indian construction projects. Journal of Construction Engineering and Management, 132(8): 871-881. doi: 10.1061/(ASCE)07339364(2006) 132:8(871).

Jaffar, N., Tharim, A.H.A. and Shuib, M.N. (2011). Factors of conflict in construction industry: A literature review. Procedia Engineering, 20: 193-202. doi: 10.1016/j.proeng.2011.11.156.

Jha, K.N. and lyer, K.C. (2007). Commitment, coordination, competence and the iron triangle. International Journal of Project Management, 25(5): 527-540. doi: 10.1016/j.jproman.2006.11.009.

Kerzner, H.R. (2013). Project Management: A Systems Approach to Planning, Scheduling and Controlling. New Jersey: John Wiley and Sons.

Kreiner, K. (2013). Organizational behaviour in construction. Construction Management and Economics, 31(11): 1165-1169. doi: 10.1016/j.jebo.2011.10.011.

Mbachu, J. and Nkado, R. (2007). Factors constraining successful building project implementation in South Africa. Construction Management and Economics, 25(1): 39-54. doi: 10.1080/01446190600601297.

Mohsin, M.A. (2011). Claim analysis of construction projects in Oman. International Journal on Advanced Science, Engineering and Information Technology, 2(2): 73-78.

Mubarak, S.A. (2010). Construction Project Scheduling and Control. New Jersey: John Wiley and Sons. doi: 10.1002/9780470912171.

Nepal, M.P., Park, M. and Son, B. (2006). Effects of schedule pressure on construction performance. Journal of Construction Engineering and Management, 132(2): 182-188. doi: 10.1061/(ASCE)07339364(2006) 132:2(182).

Neuman, W.L. (2005). Social Research Methods: Quantitative and Qualitative Approaches. Boston: Allyn and Bacon.

Oberlender, G.D. (1993). Project Management for Engineering and Construction. New York: McGraw-Hill.

Oman Tender Board. (2014). Homepage. Available at: https://www.tenderboard. gov.om/eng/.

Oxford Business Group. (2014). Oman's Construction Sector Building Up. London: Oxford Business Group. Available at: http://www.oxfordbusinessgroup. com/news/oman\%E2\%80\%99s-construction-sector-building [Accessed on October 2014].

Oyedele, L.O. (2013). Analysis of architects' demotivating factors in design firms. International Journal of Project Management, 31(3): 342-354. doi: 10.1016/j.jproman.2012.11.009.

Schatteman, D., Herroelen, W., Van de Vonder, S. and Boone, A. (2008). Methodology for integrated risk management and proactive scheduling of construction projects. Journal of Construction Engineering and Management, 134(11): 885-893. doi: 10.1061/(ASCE)07339364(2008) 134:11(885).

Sears, S.K., Sears, G.A. and Clough, R.H. (2010). Construction Project Management: A Practical Guide to Field Construction Management. New Jersey: John Wiley and Sons. 
Sun, M. and Meng, X. (2009). Taxonomy for change causes and effects in construction projects. International Journal of Project Management, 27(6): 560-572. doi: 10.1016/j.ijproman.2008.10.005.

Sunindijo, R.Y., Hadikusumo, B.H. and Ogunlana, S. (2007). Emotional intelligence and leadership styles in construction project management. Journal of Management in Engineering, 23(4): 166-170. doi: 10.1061/(ASCE)0742597X(2007)23:4(166).

Too, E.G. and Weaver, P. (2014). The management of project management: A conceptual framework for project governance. International Journal of Project Management, 32(8): 1382-1394. doi: 10.1016/j. ijproman.2013.07.006.

Turner, J.R. (1999). The Handbook of Project-Based Management. London: McGraw-Hill.

Walker, A. (2011). Organizational Behaviour in Construction. London: John Wiley and Sons.

Yang, L.R., Huang, C.F. and WU, K.S. (2011). The association among project manager's leadership style, teamwork and project success. International Journal of Project Management, 29(3): 258-267. doi: 10.1016/j.jproman.2010.03.006. 